\title{
EVALUASI PEMBELAJARAN DIKLAT MENGGUNAKAN MODEL COUNTENANCE STAKE
}

\author{
Oleh: Amalia Puspayanti \\ Balai Diklat Keagamaan Denpasar \\ Email: amalia_bdk11@yahoo.com
}

\begin{abstract}
ABSTRAK
Penelitian ini merupakan penelitian evaluasi model Countenance Stake yang bertujuan untuk mengetahui dan mendeskripsikan pembelajaran Diklat Teknis Substantif Peningkatan Kompetensi PKG dan PKB bagi Guru PAI SMA dan Guru Madrasah (MTs dan MA) di Lingkungan Kantor Kementerian Agama Kabupaten Sumbawa Tahun 2017 difokuskan pada antecedents (perencanaan), transaction (proses), dan outcomes (hasil belajar). Subjek penelitian melibatkan 39 orang peserta Diklat dan 2 orang Widyaiswara pengampu mata Diklat inti. Data yang dibutuhkan dikumpulkan melalui metode kuesioner, dokumentasi, dan observasi. Data tersebut dianalisis dengan cara membandingkan dan mencermati keterkaitan antara antecedents, transaction, dan outcomes yang dikemukan dalam intent (tujuan atau harapan) dengan apa yang terjadi dalam kegiatan (observasi). Hasil penelitian menunjukkan bahwa komponen antecedents, transaction, dan outcomes berada pada kategori amat baik dengan persentase $88,71 \%$. Sejalan dengan simpulan penelitian, direkomendasikan untuk menindaklanjuti Diklat dalam bentuk kegiatan evaluasi pasca Diklat. Widyaswara diharapkan memperbarui ilmu dan pengetahuan sesuai lingkup substansi yang disampaikan. Stakeholder/ User di wilayah kerja perlu menindaklanjuti pemberdayaan kompetensi dan keterampilan alumni pasca diklat.
\end{abstract}

Kata Kunci: Evaluasi pembelajaran Diklat, Model Countenance Stake, PKG dan PKB

\section{ABSTRACT}

This Study is the evaluation study of Countenance Stake Method aimed to comprehend and represent learning of technically substantive training in supporting PKG and PKB competence on PAl High School Teachers and Islamic School (MTS \& MA) Teachers in Ministry of Religious Affairs' Department of Sumbawa Regency 2017 focused on antecedents, transaction and outcomes. Study subjects are 39 people from training members and 2 
people from Widyaswara as mentors of the trained credit. Required data is collected by documentation method, observation and questionnaire. The data analyzed by comparing and considering relations among antecedents, transaction and outcomes introduced in the intent with experienced in activity (observation). The study shows that antecedents, transaction and outcomes component are in the best category with percentage $88,71 \%$. Rightly planned learning induce in learning process effectively and causing significant outcomes. In regarding to study conclusion, it is recommended to continue training in an activity of evaluation program in order to obtain clear data and information about prevalent member outcomes while attending in training being able to be implemented in their job. Widyaswara is required to update their knowledge and experience corresponding in their scope lectured to gain member's requirements. Stakeholders or users in the scope region need to empower members' competence and skill after training in their scope training program.

\section{Keyword: Evaluation of Training Learning, Countenance Stake Model, PKG and PKB}

\section{PENDAHULUAN}

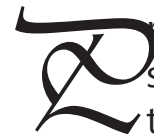

rofesionalisme sebagai seorang pendidik tidak hanya menuntut pemenuhan kualifikasi akademik dan kompetensi minimal yang dipersyaratkan, tetapi juga wajib melaksanakan tugas dan tanggungjawabnya secara utuh terkait dengan jabatan fungsional guru itu sendiri. Peraturan Menteri Negara Pendayagunaan Aparatur Negara dan Reformasi Birokrasi (Permenneg PAN dan RB) Nomor 16 Tahun 2009 mengatur secara jelas tentang jabatan guru dan angka kreditnya. Peraturan ini merupakan langkah strategis pemerintah dalam upaya mewujudkan guru yang profesional dan bermartabat. Pertanyaan yang kemudian muncul adalah apakah guru sudah memahami betul isi dan ketentuanketentuan yang mengikat, untuk kemudian bisa diimplementasikan dengan benar. Pernyataan diimplementasikan dengan benar' dimaksudkan bagaimana seorang guru menjalankan kewajiban kesehariannya sebagai pendidik dengan tidak melupakan tanggungjawab atas profesi yang dimiliki. Contoh sederhana sebagaimana diatur dalam PermenPAN dan RB ini adalah guru wajib melaksanakan Penilaian Kinerja Guru (PKG) setiap tahun, kemudian merancang kegiatan Pengembangan Keprofesian Berkelanjutan (PKB) berdasarkan kebutuhan secara berkelanjutan dalam rangka peningkatan 
kompetensi, serta menyusun dan mengajukan Daftar Usul Penetapan Angka Kredit (DUPAK) secara rutin setiap tahunnya.

Berdasarkan pengamatan peneliti dan pengalaman yang ditemui dalam berbagai kesempatan Pendidikan dan Pelatihan (Diklat), mengkhusus pada Diklat Teknis Substantif Peningkatan Kompetensi PKG dan PKB, kebanyakan guru mengakui belum melaksanakan PKG secara utuh. Selama ini guru tersebut sebatas menerima hasil yang telah diselesaikan oleh tenaga operator sekolah/madrasah, kalaupun ada yang telah mencoba melaksanakan, belum disertai dengan pemahaman yang utuh baik tentang tahapan prosesnya, syarat dan kriteria penilai maupun yang dinilai, analisis pengisian dan penskoran butir-butir kompetensi dan indikator instrumen PKG sampai pada perhitungan perolehan angka kredit tiap tahun. Perihal apa yang dimaksud dengan PKB, bagaimana merancang PKB dan melengkapi bukti fisiknya, belum dipahami betul oleh para guru tersebut. Berdasarkan informasi, penyusunan dan pengusulan DUPAK masih banyak yang menggunakan jasa orang lain (ada sesama oknum guru, pengawas, bagian kepegawaian) yang secara sukarela atau memang jelas dibayar. Ada sebagian guru yang sudah berusaha mencoba, baik dalam pelaksanaan PKG setiap tahun, melakukan penelitian, atau menyusun DUPAK, hanya saja memang dengan segala keterbatasan yang ada dan bahkan masih diikuti stigma bahwa hal tersebut cukup dilaksanakan saat berniat naik pangkat saja.

Hal-hal tersebut di atas, adalah sebagian permasalahan yang ingin diminimalisir melalui dukungan kewenangan Balai Diklat Keagamaan (BDK) Denpasar sebagai unit pelaksana teknis Diklat di daerah. BDK Denpasar menyelenggarakan Diklat Teknis Substantif Peningkatan Kompetensi PKG dan PKB dengan tujuan memberikan bekal pengetahuan, keterampilan, dan semangat menjalankan tugas dan tanggungjawab profesi guru. Tujuan Diklat tersebut kemudian memunculkan sebuah pertanyaan sederhana, apakah Diklat telah terlaksana sesuai dengan tujuannya? Atau dengan kata lain, apakah penyelenggaraan Diklat Teknis Substantif Peningkatan Kompetensi PKG dan PKB terkhusus lagi pada pelaksanaan proses pembelajarannya, telah sesuai dengan tujuan yaitu meningkatkan pengetahuan, keahlian, keterampilan dan sikap guru dalam melaksanakan tugas jabatannya secara profesional.

Tidak dapat dipungkiri pada kenyataannya terkadang para guru yang berkesempatan ikut Diklat, hanya mengikuti dan 
menggugurkan kewajibannya sebagai peserta, istilahnya hanya duduk, diam, dan dengarkan. Atau bisa juga kemungkinannya, rancangan proses pembelajaran yang dibuat dan dilaksanakan oleh Widyaiswara pengampu belum cukup membekali pengetahuan maupun pengalaman praktis kepada para peserta. Atas dasar ini, maka perlu dilakukan evaluasi terhadap proses pembelajaran Diklat Teknis Substantif Peningkatan Kompetensi PKG dan PKB, apakah telah berjalan efektif serta berdampak pada peningkatan kompetensi dan keterampilan peserta terkait substansi materi PKG dan PKB. Dengan demikian masalah yang dirumuskan dalam penelitian ini adalah "Bagaimana pembelajaran Diklat Teknis Substantif Peningkatan Kompetensi PKG dan PKB bagi Guru PAI SMA dan Guru Madrasah (MTs dan MA) di Lingkungan Kantor Kementerian Agama Kabupaten Sumbawa Tahun 2017) dievaluasi menggunakan model Countenance Stake?"

Beberapa kajian teori pendukung yang dibahas untuk dapat menjawab permasalahan tersebut adalah sebagai berikut.

\section{Evaluasi Model Countenance Stake}

Evaluasi umumnya dilakukan untuk mengukur keberhasilan program-program atau kebijakan tertentu. Penelitian evaluasi yang digunakan dalam penelitian ini adalah model Countenance Stake. Model ini dikembangkan oleh Stake. Kata Countenance berasal dari bahasa Inggris yang berarti menyetujui atau persetujuan. Arifin (2010) menjelaskan bahwa model ini adalah model evaluasi yang tepat untuk menilai pembelajaran secara kompleks Komponen minimal yang harus dijabarkan dalam model evaluasi Countenance Stake ini adalah sebagai berikut.

a. Rationale, yaitu menjelaskan pentingnya Diklat Teknis Substantif Peningkatan Kompetensi PKG dan PKB bagi guru.

b. Intent, yaitu tujuan apa yang diharapkan dari suatu program pelatihan; khususnya tujuan pembelajaran diklat PKG dan PKB termasuk semua yang direncanakan atas pembelajaran dan hasil belajar yang diinginkan.

c. Observation, yaitu apa yang dapat diamati selama pembelajaran Diklat berlangsung.

d. Antecedents, yaitu kondisikondisi yang diharapkan sebelum kegiatan pelatihan berlangsung, yakni perencanaan pembelajaran oleh Widyaiswara maupun latar belakang peserta mengikuti diklat.

e. Transaction, yaitu proses pembelajaran mata Diklat 
inti yang melibatkan peserta maupun Widyaiswara.

f. Outcomes, yaitu hasil yang diperoleh dari pelatihan mencakup pengetahuan, keterampilan, sikap dan nilainilai atau dengan mudah diartikan dengan hasil belajar peserta diklat.

g. Standards, yaitu apa yang diharapkan dari para stakeholders, yakni mengacu pada kriteria-kriteria yang terkait dalam pedoman penyelenggaraan Diklat.

h. Judgement, yaitu menilai pendekatan dan prosedur yang digunakan dalam pembelajaran Diklat, para pelatih/instruktur, dan bahanbahan.

Model evaluasi Countenance Stake dapat ditampilkan dalam matrik berikut.

Gambar 1 Matrik Evaluasi Model Countenance Stake



(Robert O Brinkerhoff, et.al. dalam Arifin, 2010:6)

\section{Pembelajaran Diklat}

Pembelajaran merupakan suatu proses yang mengandung dua jenis kegiatan yang tidak terpisahkan, yaitu belajar dan mengajar. Pembelajaran didefinisikan sebagai proses interaksi peserta didik dengan pendidik dan sumber belajar pada suatu lingkungan belajar (Depdiknas, 2003). Peserta didik dalam konteks Diklat adalah peserta Diklat sedangkan pendidik adalah Widyaiswara atau Pengajar pengampu materi. Istilah pembelajaran disini lebih dikenal dengan dikjartih yaitu proses belajar mengajar dalam Diklat baik secara klasikal dan/ atau non klasikal (KemenPAN dan RB, 2014). Pembelajaran pada program Diklat bertumpu pada prinsip pembelajaran orang dewasa atau andragogi yang menitikberatkan pada partisipasi peserta untuk menggunakan pengetahuan serta pengalaman hidupnya dalam pembelajaran. Prinsip tersebut diantaranya adalah memiliki nilai manfaat, sesuai dengan pengalaman, berkaitan dengan permasalahan seharihari, ada praktik (tidak sebatas teori), sesuai dengan kebutuhan, menarik, menuntut partisipasi aktif dan kerjasama peserta maupun fasilitator.

Belajar bagi orang dewasa akan efektif jika ada kesempatan berbicara dan mendengar, akan lebih efektif jika berkesempatan untuk melihat, dan paling efektif lagi jika berkesempatan untuk melakukan/mengerjakan. Komposisi kemampuan tersebut 
dapat digambarkan ke dalam piramida belajar (pyramida of learning) berikut.

Gambar 2

Piramida Belajar Orang Dewasa

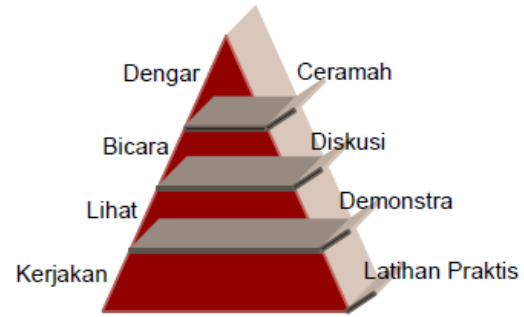

(Sudaryanto, 2016:33)

Pelaksanaan Diklat mengacu pada pedoman penyelenggaraan, perlu dievaluasi mencakup empat aspek yaitu evaluasi terhadap peserta diklat, Widyaiswara, penyelenggara, dan program diklat. Melihat keterhubungan dengan proses pembelajaran, maka dua aspek yakni evaluasi terhadap peserta dan Widyaiswara, menjadi bagian yang paling mendukung pembahasan proses pembelajaran atau dikjartih pada Diklat PKG dan PKB. Evaluasi terhadap peserta yang mencakup komponen sikap, produk, dan ujian merupakan kriteria yang dapat digunakan untuk mengevaluasi hasil proses pembelajaran. Sedangkan evaluasi terhadap Widyaiswara, dapat digunakan sebagai bagian kriteria dalam mengevaluasi pelaksanaan proses pembelajaran itu sendiri.

Berikut dijelaskan komponen dari kedua evaluasi tersebut sesuai dengan yang dijelaskan dalam Pedoman Evaluasi Penyelenggaraan Diklat Teknis (Pusdiklat, 2013).

a. Evaluasi terhadap peserta meliputi komponen sikap (30\%), produk (30\%), dan ujian (40\%). Komponen sikap mencakup perilaku, disiplin, kehadiran, prakarsa, kerjasama, partisipasi, dan tanggungjawab. Komponen produk didasarkan atas hasil kerja atau praktik atau tugas mandiri yang diberikan Widyaiswara. Sedangkan komponen ujian, didasarkan atas ujian tulis yang dilaksanakan di akhir kegiatan, mencakup kompetensi mata diklat sesuai substansi PKG dan PKB. Instrumen ujian ini berupa tes pilihan ganda dengan 4 pilihan jawaban. Ketiga komponen evaluasi ini (sikap, produk, dan ujian) selanjutnya diakumulasi menjadi nilai ratarata peserta.

b. Evaluasi terhadap Widyaiswara meliputi komponen perencanaan pembelajaran (40\%) dan proses pembelajaran (60\%). Komponen perencanaan memiliki 4 indikator yaitu persiapan bahan ajar, GBPP/RBPMD, SAP/RP, dan bahan tayang. Sedangkan untuk komponen proses pembelajaran memiliki 14 indikator yaitu pengetahuan 
dan keterampilan mengajar, penguasaan materi, sistematika penyajian, kemampuan menyajikan, penggunaan metode dan alat bantu pembelajaran, ketercapaian tujuan pembelajaran, etika, sikap terhadap peserta, cara menjawab pertanyaan peserta, penggunaan bahasa, pemberian motivasi, disiplin waktu, kerapian berpakaian, kerjasama (apabila tim).

Diklat adalah penyelenggaraan pembelajaran dan pelatihan dalam rangka mengembangkan kompetensi pegawai sesuai persyaratan jabatan masingmasing pada Kementerian Agama yang dilaksanakan paling sedikit 40 jam pelajaran, dengan durasi tiap jam pelajaran adalah 45 menit (Kemenag, 2015). Kurikulum Diklat Teknis Substantif Peningkatan Kompetensi PKG dan PKB diatur sesuai dengan standar kompetensi jabatan guru, dimana lebih diarahkan kepada tugas dan tanggungjawab atas jabatan fungsional guru dan angka kreditnya.

\section{METODE PENELITIAN}

Desain penelitian ini adalah penelitian evaluasi model Countenance Stake. Langkah evaluasi dilakukan melalui analisis matrik deskripsi dan matrik pertimbangan. Analisis matrik deskripsi dilakukan dengan mencermati dan membandingkan antara antecedents, transaction, dan outcomes yang diharapkan sesuai tujuan awal pembelajaran (intent) dengan yang teramati atau terealisasi di pelaksanaan (observation). Sedangkan pada analisis matrik pertimbangan, antecedents, transaction, dan outcomes dicermati dan dibandingkan dari sisi kesesuaiannya dengan yang distandarkan (standards, yakni mengacu pada pedoman penyelenggaraan Diklat) dan dari sisi perbedaan atau kesenjangan yang terjadi antara yang distandarkan dengan hasil pengamatan pelaksanaan pembelajaran Diklat.

Subjek dalam penelitian ini adalah peserta Diklat dan Widyaiswara pengampu materi Diklat. Peserta terdiri atas guru PAI SMA, guru MTs dan MA sebanyak 39 orang di Kantor Kementerian Agama Kabupaten Sumbawa. Sedangkan Widyaiswara pengampu materi inti adalah sebanyak 2 orang. Data yang dibutuhkan dikumpulkan melalui metode kuesioner, dokumentasi, dan observasi. Metode kuesioner menggunakan lembar kuesioner yang memuat 24 butir pernyataan yang sebagian mengadaptasi dari instrumen evaluasi pasca Diklat (Pusdiklat Tenaga Teknis Keagamaan, 2007) dan sebagian lagi peneliti rumuskan untuk 
bisa mendapatkan data yang dibutuhkan terkait indikasi komponen antecedents, transaction, maupun outcomes. Penskorannya menggunakan skala Likert dengan pilihan 1 jika tidak setuju, 2 kurang setuju, 3 setuju, dan 4 sangat setuju. Metode kedua adalah dokumentasi, dilakukan melalui pencermatan terhadap dokumen kelengkapan mengajar Widyaiswara, kurikulum dan silabus, jadwal pelaksanaan pembelajaran, rekap hasil penilaian peserta terhadap Widyaiswara, dan rekap nilai peserta. Metode ketiga adalah metode observasi, dilakukan melalui observasi terbuka dimana peneliti membuat rekaman tertulis proses pembelajaran dalam bentuk transkrip hasil pengamatan dan catatan proses pembelajaran setiap harinya. Ketiga metode tersebut digunakan sekaligus dengan tujuan sebagai triangulasi data penelitian ini, yakni ada perbandingan data antara yang diperoleh melalui kuesioner (oleh peserta), hasil observasi (oleh peneliti), pencermatan dokumen (telaah kebenaran dan kelengkapan bukti fisik). Data yang terkumpul kemudian dianalisis dengan menggunakan teknik analisis data oleh Matthew B. Miles dan Michael Huberman, yang meliputi reduksi data, penyajian data, dan penarikan simpulan atau verifikasi (Huberman, 1992:16). Reduksi data dilakukan mulai dari pencermatan dokumen kelengkapan bahan diklat yang disiapkan oleh
Widyaiswara, kemudian pengumpulan data saat proses pembelajaran Diklat berlangsung, sampai pada pencermatan dokumen data rekap nilai peserta dan Widyaiswara setelah proses pembelajaran

berlangsung. Penyajian data meliputi kuantifikasi data maupun uraian deskriptif. Data yang diperoleh melalui teknik dokumentasi dan observasi, akan disajikan secara deskriptif naratif. Sedangkan data yang diperoleh melalui metode kuesioner disajikan dalam bentuk deskriptif persentase. Sesuai dengan desain penelitian evaluasi model Countenance Stake, proses penyajian data dilengkapi dengan analisis yang meliputi analisis logis dan empirik. Penarikan simpulan atau verifikasi dalam penelitian ini dilakukan dengan membuat pertimbangan atau keputusan apakah pembelajaran Diklat PKG dan PKB telah sesuai dengan tujuan yang diharapkan semula maupun kriteria-kriteria sebagaimana yang distandarkan Pada penarikan simpulan dilakukan konversi hasil evaluasi ketiga fokus penelitian (antecedents, transaction, dan outcomes) ke dalam bentuk kualitatif untuk menentukan kategori ketercapaian proses pembelajaran. Rentang nilai disajikan sebagai berikut:

$\begin{array}{lll}\text { Amat baik } & : & 85 \%-100 \% \\ \text { Baik } & : & 70 \%-84,99 \% \\ \text { Cukup } & : & 56 \%-69,99 \% \\ \text { Kurang } & : & 0 \quad-55,99 \% \\ \text { (Arikunto dalam Lukum, 2015:31) }\end{array}$




\section{TEMUAN DAN PEMBAHASAN}

\section{Pelaksanaan} pembelajaran yang dievaluasi dalam penelitian ini difokuskan dalam 3 hal, yaitu antecedent, transaction, dan outcomes. Ketiga fokus tersebut berawal dari rational pentingnya penyelenggaraan Diklat Teknis Substantif sendiri yang bertujuan memberikan pengetahuan dan keterampilan yang bersifat substantif dalam rangka pencapaian kompetensi yang terkait dengan pekerjaan yang bersangkutan sehingga mampu melaksanakan tugas dan tanggungjawabnya secara profesional (Kemenag, 2015). Guru wajib memahami segala ketentuan mulai dari unsurunsur kegiatan guru yang dapat dinilai angka kreditnya, syarat dan mekanisme pelaksanaan PKG, sampai pada prosedur dan teknis persyaratan pengajuan DUPAK. Hal pokok yang perlu dipahami dan dikuasai ini menjadi sasaran target pembelajaran Diklat sehingga sejalan dapat dijadikan dasar pertimbangan yang perlu diperhatikan dalam mencermati

fokus penelitian, apakah perencanaan atau persiapan mengajar Widyaiswara, proses pembelajaran yang dilakukan, maupun hasil belajar yang ditargetkan, telah direncanakan dan dilaksanakan dengan matang dalam rangka memfasilitasi peserta Diklat dalam pencapaian sasaran Diklat dimaksud. Berikut dijelaskan temuan hasil penelitian.

\section{Hasil}

\section{a. Data Antecedents}

Fokus pertama yang dibahas adalah komponen antecedents yaitu perencanaan atau persiapan mengajar Widyaiswara dan latar belakang peserta mengikuti Diklat. Data untuk fokus antecedents dapat disajikan secara ringkas dalam matrik berikut.

Tabel 1 Description Matrix Komponen Antecedents

\begin{tabular}{|c|c|}
\hline \multicolumn{2}{|r|}{ Description Matrix } \\
\hline Intent & Observation \\
\hline $\begin{array}{l}\text { Perencanaan atau persiapan } \\
\text { mengajar Widyaiswara } \\
\text { meliputi membuat bahan } \\
\text { Diklat yakni bahan ajar, } \\
\text { RBPMD, RP, bahan tayang. }\end{array}$ & $\begin{array}{l}\text { Tim Widyaiswara membuat bahan Diklat lengkap meliputi } \\
\text { bahan ajar, RBPMD, RP, bahan tayang. Menjabarkan } \\
\text { materi berdasarkan kurikulum dan silabus, mengacu pada } \\
\text { Permenneg PAN \& RB No. } 16 \text { Tahun 2009, Permendiknas } \\
\text { No. } 35 \text { Tahun 2010, Peraturan Bersama Mendiknas dan } \\
\text { Kepala BKN No. No.14/2010 dan No 03/V/PB/2010, } \\
\text { Buku Pedoman PKG dan PKB, bahan yang diperoleh saat } \\
\text { TOT. }\end{array}$ \\
\hline
\end{tabular}




\begin{tabular}{|l|l|}
\hline $\begin{array}{l}\text { Bahan Diklat dibuat mengacu } \\
\text { pada kurikulum dan silabus } \\
\text { serta jadwal pelaksanaan. }\end{array}$ & $\begin{array}{l}\text { Mempersiapkan lembar kerja untuk latihan. } \\
\begin{array}{l}\text { Menyiapkan lembar kerja } \\
\text { untuk latihan. }\end{array}\end{array}$ \\
\hline $\begin{array}{l}\text { Latar belakang peserta } \\
\text { adalah } 100 \% .\end{array}$ \\
$\begin{array}{l}\text { mengikuti Diklat atas dasar } \\
\text { kebutuhan. }\end{array}$ & $\begin{array}{l}\text { Penunjukan peserta oleh instansi pengirim telah } \\
\text { didasarkan atas kebutuhan, dengan nilai } \mathbf{7 9 , 6 1 \% ~ p a d a ~} \\
\text { kategori baik. }\end{array}$ \\
\hline
\end{tabular}

\section{b. Data Transaction}

Komponen berikutnya yang dievaluasi adalah komponen transaction. Transaction berkenaandengan pelaksanaan proses pembelajaran yang berhubungan dengan kompetensi pengelolaan dan substansi Widyaiswara serta kebermanfaatan pembelajaran Diklat bagi peserta. Secara ringkas data untuk fokus transaction dapat disajikan dalam matrik berikut.

Tabel 2 Description Matrix Komponen Transaction

\begin{tabular}{|c|c|}
\hline \multicolumn{2}{|r|}{ Description Matrix } \\
\hline Intent & Observation \\
\hline $\begin{array}{l}\text { Widyaiswara memiliki } \\
\text { kompetensi pengelolaan } \\
\text { pembelajaran dan kom- } \\
\text { petensi substansi. }\end{array}$ & $\begin{array}{l}\text { Kompetensi pengelolaan pembelajaran dan substansi Widy- } \\
\text { aiswara menunjukkan nilai rata-rata } 92,63 \text { dengan pre- } \\
\text { dikat amat baik berdasarkan rekap penilaian peserta terh- } \\
\text { adap Widyaiswara. Sedangkan berdasarkan data kuesioner, } \\
\text { menunjukkan nilai } \mathbf{8 9 , 2 5 \%} \text { atau kategori amat baik. } \\
\text { Widyaiswara telah melaksanakan pembelajaran dengan ti- } \\
\text { dak hanya menyampaikan teori saja, tetapi banyak meman- } \\
\text { faatkan latihan-latihan menggunakan lembar kerja, praktik } \\
\text { pengisian instrumen dalam PKG, simulasi pengisian dan } \\
\text { pengusulan form DUPAK, terbuka dengan segala pertanyaan } \\
\text { tentang permasalahan yang dihadapi guru di sekolah/ma- } \\
\text { drasah terkait substansi materi, dan memotivasi peserta un- } \\
\text { tuk bisa dan mau melaksanakan segala kewajiban tersebut. }\end{array}$ \\
\hline $\begin{array}{l}\text { Proses pembelajaran } \\
\text { dapat memberikan ke- } \\
\text { sempatan luas bagi pe- } \\
\text { serta untuk berpartisi- } \\
\text { pasi aktif, memperoleh } \\
\text { tambahan pengetahuan } \\
\text { dan keterampilan sesuai } \\
\text { kebutuhan, tidak sebatas } \\
\text { teori saja (ada nilai ke- } \\
\text { bermanfaatan) }\end{array}$ & $\begin{array}{l}\text { Kebermanfaatan pembelajaran terhadap peserta Diklat } \\
\text { menunjukkan hasil dengan nilai persentase sebesar } \mathbf{8 4 , 2 1 \%} \\
\text { atau kategori baik. }\end{array}$ \\
\hline
\end{tabular}


c. Data Outcomes

Komponen terakhir yang dievaluasi adalah komponen outcomes yaitu hasil belajar peserta Diklat. Komponen ini diindikasikan dengan perubahan sikap, pengetahuan, dan keterampilan yang terjadi pada peserta. Evaluasi pada indikator ini menggunakan data utama melalui pencermatan terhadap rekapitulasi nilai peserta. Rekap tersebut berisi nilai-nilai dari unsur sikap dengan bobot $30 \%$, pengetahuan $40 \%$, dan produk yang bisa disetarakan untuk menilai keterampilan sebesar 30\%. Hasil akhir pada rekap tersebut menunjukkan 39 peserta dinyatakan lulus. Unsur sikap, pengetahuan, dan keterampilan menghasilkan nilai rata-rata masing-masing adalah 91,4\%, 88,79\%, dan 88,64\%. Data komponen outcomes ini dapat disajikan dalam matrik berikut.

Tabel 3 Description Matrix Komponen Outcomes

\begin{tabular}{|l|l|}
\hline \multicolumn{3}{|l|}{ Description Matrix } \\
\hline Intent & Observation \\
\hline Terjadi perubahan & Persentase nilai sikap peserta 91,4\%., \\
sikap, pengetahuan, dan & dimana peserta aktif bertanya, menanggapi, \\
keterampilan peserta setelah & menyelesaikan tugas. \\
mengikuti pembelajaran & Persentase penguasaan pengetahuan 88,79\% \\
Diklat. & dan keterampilan 88,64\%. \\
\hline
\end{tabular}

\section{Pembahasan}

Data yang tersaji di atas, dapat dijelaskan masing-masing sebagai berikut.

\section{a. Pembahasan antecedents}

Sesuai dengan tujuan Diklat dan merujuk kepada ketentuan dalam panduan penyelenggaraan Diklat teknis, maka Widyaiswara wajib membuat perencanaan pembelajaran yang dibuktikan dengan kelengkapan dokumen berupa bahan ajar, GBPP/RBPMD dan SAP/RP, bahan tayang (teori hal.4). Bahan diklat ini dibuat dengan berpedoman pada kurikulum dan silabus yang tersedia. Materi-materi yang termuat di dalamnya dijabarkan dalam rangka penguasaan atas ketentuan-ketentuan yang diatur dalam Permenneg PAN dan RB Nomor 16 Tahun 2009. Widyaiswara juga seyogyanya menyiapkan lembar-lembar kerja sebagai sarana untuk berlatih bagi peserta 
karena mengingat Diklat ini tidak sebatas membekali pengetahuan tetapi juga pada penguasaan keterampilan yang berhubungan dengan teknis-teknis prosedur dan persyaratan yang harus dipenuhi terkait jabatan fungsional guru dan angka kreditnya. Tak kalah penting juga adalah jadwal Diklat yang mesti disusun oleh panitia paling lambat 7 hari sebelum pelaksanaan. Selanjutnya dari sisi peserta, bisa diamati apakah latar belakang mengikuti Diklat memang didasarkan atas kebutuhan, dalam arti melihat prioritas di sekolah/madrasah maupun pangkat/golongan yang bersangkutan sehingga perlu ditetapkan sebagai peserta Diklat, yang nantinya diharapkan minimal bisa menerapkan untuk diri sendiri serta mengimbaskan kepada teman guru sejawat di sekolah atau madrasahnya. Ketentuanketentuan ini merupakan kondisi ideal sebagai intent yang diharapkan dalam fokus antecedents.

Berikut dibahas apa yang ditemukan pada kondisi sesungguhnya atau yang terjadi di kenyataan dilihat dari perencanaan dan persiapan mengajar Widyaiswara. Menurut informasi yang diperoleh dari panitia dan rekap penilaian terhadap kelengkapan bahan Diklat yang dibuat oleh Widyaiswara, dapat disampaikan bahwa tim Widyaiswara telah membuat bahan Diklat berupa bahan ajar, RBPMD dan RP, bahan tayang dari enam mata Diklat inti dan diserahkan kepada panitia sebelum Diklat berjalan. Bahan diklat ini juga sudah diperiksa oleh Kepala Balai saat pengajuan bukti fisik dari pelaporan atas kinerja harian Widyaiswara. Secara format, telah mengikuti ketentuan yang ada, dari segi isi, telah disesuaikan dengan kurikulum dan silabus yang tersedia dimana mengikuti kompetensi dan indikatorindikator pencapaian kompetensi dalam penjabaran materinya, merujuk juga pada peraturanperaturan yang berlaku seperti Permenneg PAN dan RB Nomor 16 Tahun 2009, Permendiknas Nomor 35 Tahun 2010, Peraturan Bersama Mendiknas dan Kepala BKN No.14/2010 dan No 03/V/ PB/2010, Buku Pedoman PKG dan $P K B$, serta sumber lain yang mendukung seperti bahan-bahan yang diperoleh saat Widyaiswara mengikuti TOT. Lembar-lembarkerja pun disiapkan oleh tim Widyaiswara agar ada kesempatan berlatih bagi peserta Diklat sehingga tidak hanya pemahaman yang didapat tetapi juga pengalaman praktis dan keterampilan atas substansi dimaksud (sesuai dengan prinsip belajar orang dewasa, teori hal. 3). Lembar kerja tersebut terdiri atas lembar evaluasi diri guru sebagai latihan melakukan penilaian kinerja formatif, kemudian lembar kerja berupa instrumen PKG yang diperuntukkan agar 
peserta memahami seluruh butir kompetensi beserta indikatorindikator yang menjadi kriteria penilaian, lengkap dengan catatan deskripsi yang harus dibuat beserta lampiran dokumen kelengkapannya, sampai pada cara mengkoversi perolehan nilai kinerja ke perolehan angka kredit per tahun, yang mana ini merupakan contoh PKG sumatif. Tidak hanya PKG, untuk PKB pun disediakan rancangan berlatih untuk membuat laporan Pengembangan Diri (PD) yang langsung mengambil contoh pada Diklat PKG dan PKB saat itu. Selain itu, lembar kerja disediakan juga untuk berlatih mengisi form usulan DUPAK yang mana dimaksudkan peserta memahami cara yang benar memasukkan nilainilai yang diperoleh baik dari unsur utama maupun penunjang beserta cara melengkapi dan mengurutkan bukti fisik yang diperlukan. Bahan Diklat maupun lembar kerja yang disediakan ini dimaksudkan untuk dapat mengakomodasi struktur materi yang diatur dalam kurikulum dan silabus yang tersedia sehingga peserta bisa paham sekaligus terampil dalam hal apa saja yang wajib dilakukan terkait jabatan fungsional yang dimilikinya. Bahan tayang dan lembar kerja telah dibuat dan dirancang sedemikian rupa untuk dimanfaatkan secara proporsional selama Diklat berlangsung sesuai dengan jadwal yang disusun oleh panitia, mulai dari hari pertama sampai hari terakhir. Jika dinilai dari keempat bahan Diklat yang telah dipenuhi oleh tim Widyaiswara, maka nilainya adalah $100 \%$.

Berkenaan dengan latar belakang peserta mengikuti Diklat, jika dicermati dari pilihan peserta pada pernyataan pertama kuesioner, diperoleh nilai $79,61 \%$. Nilai $79,61 \%$ adalah pada kategori baik, yang artinya bahwa penunjukan sebagai peserta Diklat memang telah didasarkan atas kebutuhan riil sekolah atau madrasah. Data ini diperkuat juga oleh data dari kuesioner pra Diklat pada butir yang menanyakan apakah peserta sudah atau belum pernah mengikuti Diklat sejenis, yang sebagian besar menyatakan belum pernah mengikuti Diklat sejenis sehingga tepat kiranya bisa dikatakan latar belakang peserta mengikuti Diklat sudah didasarkan atas kebutuhan.

Jika diambil rata-rata persentase dari kedua indikator pada komponen antecedents, maka nilai yang diperoleh adalah sebesar $89,80 \%$ yang artinya untuk komponen antecedents adalah pada kategori amat baik. Hasil ini dapat diringkas dalam matrik judgement berikut. 
Tabel 4 Judgement Matrix Komponen Antecedents

\begin{tabular}{|c|c|}
\hline \multicolumn{2}{|c|}{ Judgement Matrix } \\
\hline Standard & Judgement \\
\hline $\begin{array}{l}\text { Perencanaan pembelajaran Widy- } \\
\text { aiswara mencakup bahan ajar, RBPMD, } \\
\text { RP, bahan tayang, dan lembar kerja. } \\
\text { Bahan Diklat dibuat dalam rentang } \\
\text { waktu } 7 \text { hari sebelum pelaksanaan dan } \\
\text { diserahkan kepada panitia sebelum } \\
\text { Diklat berjalan. }\end{array}$ & $\begin{array}{l}\text { Widyaiswara telah membuat dan memenuhi } \\
\text { semua kelengkapan perencanaan pembelaja- } \\
\text { ran. }\end{array}$ \\
\hline $\begin{array}{l}\text { Peserta Diklat belum pernah mengikuti } \\
\text { Diklat sejenis. } \\
\text { Peserta Diklat adalah guru PNS. }\end{array}$ & $\begin{array}{l}\text { Penunjukan calon peserta oleh instansi pengi- } \\
\text { rim telah didasarkan pada kebutuhan (semua } \\
\text { berstatus PNS). } \\
\text { Kategori komponen antecedents adalah amat } \\
\text { baik dengan nilai } 89,80 \% \text {. }\end{array}$ \\
\hline
\end{tabular}

\section{b. Pembahasan transaction}

Jika dicermati dari sisi intent, harapanyang diinginkan dariproses pembelajaran ini, tentunya dari segi kompetensi memang idealnya Widyaiswara memiliki kompetensi pengelolaan pembelajaran, kompetensi substansi, kompetensi kepribadian, dan kompetensi sosial, agar mampu mengelola pembelajaran secara maksimal. Tidak hanya sekedar menciptakan suasana pembelajaran yang menyenangkan bagi peserta, tetapi menguasai betul substansi materi dan mampu menyajikannya secara benar dan sistematis melalui metode-metode yang tepat. Sikap dan etika maupun kemampuan berbahasa Indonesia yang baik dan benar juga diperlukan dalam hal ini. Selain juga kemampuan untuk membangun motivasi kepada peserta seperti mengubah mindset yang selama ini kurang tepat, contohnya kebiasaan tidak mengirim DUPAK jika tidak bermaksud naik pangkat ataupun mengirim DUPAK dengan cara dibuatkan oleh orang lain.

Perihal lain yang perlu dikaji dari pelaksanaan proses pembelajaran ini adalah sisi kebermanfaatan proses pembelajaran tersebut. Berpedoman pada prinsip belajar orang dewasa (teori hal. 3), tentu diharapkan proses pembelajaran nantinya dapat memberikan kesempatan seluas-luasnya bagi peserta untuk ikut berpartisipasi aktif dalam pembelajaran, bisa berbagi pengetahuan dan pengalaman diantara peserta maupun dengan Widyaiswara.

Pembelajaran perlu diselingi oleh latihan-latihan atau praktik dan simulasi sehingga memberikan 
pengalaman langsung yang membangun kepada pemahaman dan keterampilan atas substansi materi yang dipelajari.

Apa yang diharapkan sebagaimana yang dikemukakan dalam bagian intent, tidak banyak perbedaan yang ditemukan pada kondisi sebenarnya saat proses pembelajaran Diklat berlangsung. Fakta dan informasi yang tertuang dalam transkrip hasil pengamatan dan catatan proses pembelajaran, didukung oleh data tentang penguasaan kompetensi Widyaiswara dari kuesioner yang telah disebar dengan butir pernyataan nomor 8-13, seputar kemampuan Widyaiswara dalam penguasaan materi dan kemampuan menyajikannya dengan berbagai metode dan media yang dibutuhkan. Tampak pada rekap hasil kuesioner bahwa penguasaan kompetensi Widyaiswara pada capaian persentase sebesar $89,25 \%$ dengan kategori amat baik. Data ini didukung oleh data yang diperoleh dari rekap penilaian peserta terhadap Widyaiswara yang menunjukkan nilai 92,63 atau kategori amat baik untuk tim Widyaiswara.

Keenam butir pernyataan pada indikator ini dapat dijelaskan satu per satu sebagai berikut. Butir 8 yang menyatakan Widyaiswara menguasai substansi materi yang disampaikan, didukung oleh riwayat pengalaman mengajar Widyaiswara yang sudah sekian kali mengampu materi pada Diklat sejenis, ditambah dengan memanfaatkan berbagi wawasan pengetahuan dengan teman sejawat Widyaiswara di saat ada peraturan-peraturan baru yang perlu ditanggapi atau dipahami. Penguasaan materi dapat diamati dari kebenaran substansi materi yang disampaikan, disamping juga kemampuan Widyaiswara menjawab pertanyaan-pertanyaan dari peserta (tertuang dalam transkrip catatan pengamatan).

Butir ke 9 dengan pernyataan, Widyaiswara mampu memberikan motivasi kepada peserta Diklat untuk semangat dalam mengikuti proses pembelajaran, dapat dijelaskan dimana berawal dari pertemuan hari pertama dan materi pertama, Widyaiswara memberi penjelasan tentang pokok-pokok perubahan yang ada dalam peraturan baru dibandingkan dengan peraturan lama, disana peserta mulai tertarik untuk serius mengikuti proses pembelajaran secara utuh, peserta sendiri mengakui bahwa hal ini bukan sesuatu yang baru tapi justru belum dipahami betul dan berjalan sesuai aturan (pengakuan peserta saat menyampaikan kesan pesan di upacara penutupan). Terlihat dari antusias peserta dalam bertanya, menanggapi penyampaian Widyaiswara yang peserta bandingkan dengan 
pengalaman ataupun kendala yang pernah dialami di tempat tugas, keaktifan peserta mengerjakan dan menyelesaikan latihan yang diberikan, dan sebagainya. Semua ini bisa dikatakan sebagai buktiyang teramati dari adanya kemampuan Widyaiswara memotivasi peserta untuk mengikuti pembelajaran.

Selanjutnya, butir ke 10 adalah Widyaiswara mampu menerapkan pendekatan pembelajaran orang dewasa (andragogi) dalam penyampaian materi dan mampu memfasilitasi harapan peserta. Transkrip catatan pengamatan menunjukkan bahwa skenario pembelajaran Widyaiswara telah dilaksanakan sedemikian rupa untuk menciptakan suasana pembelajaran yang sifatnya tidak monoton, seperti contohnya di pagi hari untuk mengawali pembelajaran, Widyaiswara mengajak peserta untuk melakukan senam atau gerakan-gerakan untuk memusatkan konsentrasi sekaligus menarik perhatian awal peserta. Pembelajaran juga dikemas tidak hanya menyampaikan materi secara teori tetapi diselingi oleh latihan dan tanya jawab dengan peserta. Di saat ada pertanyaanpertanyaan menyangkut kendala atau permasalahan di tempat kerja, Widyaiswara tidak langsung mengatakan bahwa yang salah adalah salah tetapi dengan cara mengarahkan pada pokok-pokok pikiran yang menyadarkan akan kebenaran yang sesungguhnya.
Satu contoh seperti saat peserta menyampaikan pengalaman salah satu teman yang berada pada golongan III.c dimintai 1 laporan Penelitian Tindakan Kelas (PTK) untuk syarat naik ke III.d, dan satu lagi teman di golongan III.d dimintai laporan PTK sebanyak 3. Widyaiswara tidak langsung menjawab bahwa hal itu salah, tetapi mengajak peserta untuk melihat dan memahami syarat kenaikan pangkat di setiap jenjang, kelengkapan sub unsur pengembangan diri, publikasi ilmiah, dan/atau karya inovasi yang harus dipenuhi, dan ini berpedoman kepada Permenneg PAN RB Nomor 16 Tahun 2009 maupun Permendiknas Nomor 35 Tahun 2010. Jadi apa yang disampaikan oleh Widyaiswara didasarkan atas peraturan atau pedoman yang berlaku, serta banyak memberikan alternatif-alternatif kegiatan yang bisa peserta lakukan untuk memaksimalkan angka kredit yang dibutuhkan maupun kewajiban yang harus dilakukan. Penjelasan ini paling tidak bisa memberikan gambaran bahwa Widyaiswara memang sudah mampu menerapkan pendekatan pembelajaran orang dewasa, yang tentu masih perlu terus dikembangkan dan disempurnakan lagi.

Butir berikutnya adalah butir ke 11 yaitu Widyaiswara mampu menerapkan berbagai strategi dan teknik pembelajaran yang relevan 
dengan materi yang disampaikan. Butir ini bisa dicermati dari strategi pembelajaran yang diterapkan oleh Widyaiswara, sebagaimana yang telah diungkapkan bahwa memang dihadirkan latihanlatihan dalam bentuk lembar kerja yang diperuntukkan melatih keterampilan sesuai bahasan yang diangkat. Seperti contoh saat menjelaskan tentang PKG formatif yang berupa kegiatan Evaluasi Diri Guru (EDG), tentunya tidak bisa hanya dijelaskan secara teori tetapi harus langsung dipraktikkan dengan bekerja mengisi lembarlembar EDG. Selain itu, dalam mempelajari konsep PKG, Widyaiswara juga memberikan contoh praktik langsung pengisian instrumen PKG. Aplikasi intrumen PKG ditunjukkan dan dicontohkan langsung cara pengisiannya, mulai dari mencermati kompetensi dan indikator-indikator serta kriteria di dalamnya, sampai pada penentuan skor dan perhitungan konversi ke angka kredit 1 tahun. Jadi tidak hanya membayangkan bagaimana mekanisme PKG tetapi sudah diberikan pengalaman belajar langsung tentang bagaimana mengisi instrumen PKG secara benar. Praktik lain dicontohkan juga saat membahas materi PKB. Setelah paham teori tentang PKB, peserta diarahkan untuk praktik langsung membuat laporan Pengembangan Diri dari Diklat PKG dan PKB yang diikuti tersebut. Terakhir dari semua yang telah dipelajari secara teori dan praktik,
Widyaiswara mengarahkan peserta untuk mensimulasikan bagaimana menyusun usulan DUPAK sesuai dengan contoh-contoh kegiatan yang sudah dilakukan dan dimiliki persyaratannya oleh masingmasing peserta. Jadi dari sini bisa tergambar bahwa sudah tampak strategi dan teknik yang dilakukan Widyaiswara dalam mengelola pembelajaran sesuai materi yang disampaikan. Contoh penggunaan aplikasi instrumen PKG seperti yang telah dijelaskan sebelumnya, menjawab pernyataan butir ke 12 yaitu Widyaiswara mampu memanfaatkan alat bantu dan media pembelajaran dalam proses pembelajaran.

Butir terakhir, butir 13 yaitu Widyaiswara mampu melaksanakan evaluasi pembelajaran yang memungkinkan bagi peserta Diklat untuk memperbaiki berbagai kekurangan. Karena evaluasi terakhir oleh pihak panitia pelaksana dilakukan dengan cara tes tulis, Widyaiswara mengambil alternatif evaluasi melalui tagihan tugas-tugas yang dikerjakan sesuai dengan lembar kerja yang diselesaikan, mulai dari isian lembar kerja EDG, instrumen PKG, laporan PD dan format usulan DUPAK dari maisngmasing peserta. Lembar kerja ini semuanya dikoreksi dan diberi catatan bagi yang perlu diperbaiki atau dilengkapi. Sekaligus menjadi bagian penguatan dari Widyaiswara kepada peserta, dan 
tagihan ini juga menghasilkan nilai produk yang kemudian diserahkan kepada pihak akademis.

$\begin{array}{ccc}\text { Data } & \text { kedua yang } \\ \text { berhubungan } & \text { dengan proses }\end{array}$ pembelajaran adalah data tentang kebermanfaatan pembelajaran. Indikator ini mencakup butir 2 s.d. 7, 14 s.d. 17, dan 23-24, yang membahas kebermanfaatan pembelajaran Diklat ditinjau dari kurikulum dan silabusnya, kemudian pemanfaatan sumber dan media pembelajaran, serta implementasi hasil Diklat nantinya. Mulai dari butir 2, sistematika materi Diklat yang saudara ikuti telah disusun dan dilaksanakan secara konsisten. Peserta sebagian besar menyatakan setuju, kekonsistenan ini bisa diamati dimana pembelajaran telah dilaksanakan sesuai dengan jadwal yang disusun oleh panitia, waktu sebagian diatur untuk penyampaian teori dan sebagian untuk praktik. Tidak hanya belajar di kelas tetapi juga ada sebagian waktu yang memang diberikan kepada peserta untuk memanfaatkan dalam kegiatan mandiri di rumah yakni dimanfaatkan untuk menyelesaikan tugas-tugas lembar kerja yang diberikan. Butir 3 yaitu alokasi jumlah jam pelajaran yang tersedia dalam kegiatan Diklat telah mencukupi bagi penguasaan seluruh substansi materi. Ada sebagian peserta yang mengakui memang masih merasakan kurang. Tentunya jika coba untuk dipahami bahwa daya penerimaan setiap orang berbeda-beda baik kualitas maupun kuantitasnya. Tetapi sudah berupaya diminimalisir oleh Widyaiswara, didasari oleh teori pembelajaran orang dewasa bahwa pembelajaran akan lebih efektif jika ada kesempatan untuk melakukan atau mengerjakan (teori hal. 4). Sebagaimana yang telah dijelaskan sebelumnya, peserta diberi kesempatan untuk langsung berlatih melalui lembar kerja agar mendapat pengalaman dan menjadi sesuatu yang bisa diingat dalam waktu lebih lama. Hanya memang kembali lagi pada kemampuan dan daya tangkap setiap peserta. Butir 4 yaitu materi Diklat disampaikan selaras dengan upaya pencapaian kompetensi (tujuan pembelajaran) yang diinginkan. Pernyataan ini tentunya sejalan dengan kenyataan dimana materi yang disampaikan oleh Widyaiswara telah merujuk pada kurikulum silabus dengan kompetensi dan indikator-indikator yang telah ditentukan. Penjelasan ini sekaligus menjawab butir 6 yaitu materi yang disampaikan oleh Widyaiswara telah mengacu pada ketentuan kurikulum silabus dan benar-benar sesuai dengan harapan saudara. Butir 5 yaitu materi yang disampaikan relevan dengan tugas/jabatan saudara. Pernyataan ini sudah langsung bisa dijawab bahwa memang relevan karena menyangkut jabatan fungsional guru dalam pemenuhan angka kreditnya. Butir 7 yaitu 
menanyakan apakah terdapat relevansi antar materi Diklat sehingga secara sistematik mampu membekali upaya pencapaian standar kompetensi yang saudara perlukan. Pernyataan ini tentu sudah bisa dijawab juga dengan penjelasan sebelumnya. Butir 1416 yang menyatakan sumber dan media belajar yang tersedia telah mencukupi kebutuhan dan sesuai dengan metode pembelajaran. Widyaiswara telah memberikan materi secara lengkap kepada peserta baik itu bahan tayang, file pdf peraturan-peraturan, buku pedoman PKG dan PKB, file lembar kerja, aplikasi instrumen PKG, format usulan DUPAK dan contoh bukti fisik kelengkapan persyaratannya. Selain itu juga pembelajaran bersifat interaktif, tidak hanya bersumber dari Widyaiswara namun juga menggali dan menerima pemikiranpemikiran yang datang dari peserta Diklat. Butir 17 tentang dukungan kenyamanan dari ruang belajar yang tersedia, sebagian besar peserta menyatakan tidak setuju dengan arti ruang belajar dirasa kurang nyaman. Hal ini dikarenakan ruang belajar hanya memanfaatkan ruang kelas yang ada di MAN 1 Sumbawa, bukan di sebuah tempat yang khusus diperuntukkan sebagai ruang belajar suatu kegiatan Diklat sehingga memang perlu dimaklumi dengan segala keterbatasan yang ada hanya yang penting adalah alat tulis dan media yang diperlukan bisa tersedia. Butir terakhir yakni butir 23 dan 24 tentang pernyataan implementasi hasil Diklat yang menegaskan kepada dukungan pimpinan di tempat tugas untuk bisa mempraktikkan hasil Diklat sekaligus mengimbaskan kepada teman guru di sekolah atau madrasah masing-masing.

Penjelasan butir-butir di atas pada akhirnya menunjukkan hasil persentase perolehan sebesar $84,21 \%$ yang menyatakan bahwa kebermanfaatan hasil Diklat terhadap peserta adalah pada kategori baik.

Ringkasan penjelasan ini dapat disajikan ke dalam bentuk matrik judgement berikut.

Tabel 5 Judgement Matrix Komponen Transaction

\begin{tabular}{|c|c|}
\hline \multicolumn{2}{|c|}{ Judgement Matrix } \\
\hline Standard & Judgement \\
\hline $\begin{array}{l}\text { Widyaiswara memiliki pengetahuan dan } \\
\text { keterampilan mengajar, menguasai materi, } \\
\text { menyajikan materi secara sistematis, } \\
\text { terampil menggunakan metode serta alat } \\
\text { bantu pembelajaran, menjaga sikap dan } \\
\text { etika kepada peserta, mampu menjawab } \\
\text { pertanyaan peserta, kemampuan berbahasa }\end{array}$ & $\begin{array}{l}\text { Kompetensi dan proses pembelajaran } \\
\text { yang dilaksanakan berada pada kategori } \\
\text { amat baik dengan nilai rata-rata } \mathbf{8 6 , 7 3 \%} \text {. } \\
\text { Widyaiswara telah menunjukkan } \\
\text { pengelolaan pembelajaran dan } \\
\text { penguasaan substansi materi melalui } \\
\text { proses pembelajaran yang memberi }\end{array}$ \\
\hline
\end{tabular}




\begin{tabular}{|l|l|}
\hline $\begin{array}{l}\text { yang baik dan benar, memberikan motivasi } \\
\text { kepada peserta, disiplin waktu, dan } \\
\text { menjaga kerapian berpakaian. }\end{array}$ & $\begin{array}{l}\text { kesempatan luas bagi peserta untuk } \\
\text { berpartisipasi aktif dan tidak hanya } \\
\text { memperoleh teori tetapi juga praktik } \\
\text { langsung dalam rangka pembentukan } \\
\text { keterampilan terkait jabatan fungsional } \\
\text { guru dan angka kreditnya. }\end{array}$ \\
\hline $\begin{array}{l}\text { Proses pembelajaran berprinsip pada } \\
\text { pembelajaran orang dewasa (andragogi), } \\
\text { yang memiliki nilai manfaat, sesuai dengan } \\
\text { pengalaman, praktis, sesuai kebutuhan, } \\
\text { menarik, membangun kerjasama, dengan } \\
\text { metode tanya jawab, diskusi, praktik, } \\
\text { simulasi, dsb. }\end{array}$ & \\
\hline
\end{tabular}

\section{Pembahasan outcomes}

Intent atau tujuan yang diharapkan pada bagian outcomes ini adalah hasil belajar peserta Diklat, yakni perubahan sikap, pengetahuan, dan keterampilan.

Unsur sikap yang dibobot $30 \%$ secara sederhana bisa disetarakan dengan perolehan maksimum 30 (skala 100). Rekap nilai menunjukkan hasil bahwa dari 39 peserta, rata-rata nilai adalah 27,42 atau jika dipersentase bernilai $91,4 \%$.. Berdasarkan pengamatan peneliti saat proses pembelajaran berlangsung, sebagian besar peserta sangat aktif mengikuti pembelajaran, baik aktif saat konsep materi disampaikan yakni melalui tanya jawab, maupun saat praktik menyelesaikan lembar kerja-lembar kerja yang tersedia, dengan bertanya saat mengalami kesulitan maupun menyegerakan penyelesaiannya sampai pada mengumpulkan tugas tepat waktu.
Unsur kedua adalah pengetahuan. Penguasaan pengetahuan dalam penelitian ini dievaluasi menggunakan telaah hasil tes ujian akhir peserta dan melalui kuesioner. Hasil ujian tulis menunjukkan bahwa rata-rata nilai peserta adalah 27,37 (dengan bobot 30\%) yang jika dipersentase menghasilkan nilai 91,23\%. Selain melalui telaah nilai ujian tulis, data tersebut terkumpul juga melalui kuesioner dengan butir pernyataan pada butir nomor 18-21. Butir pernyataan 18 sampai dengan 21 tersebut berturut-turut adalah tentang substansi materi yang memberikan pemahaman tentang unsur-unsur kegiatan guru yang dinilai angka kreditnya (utama dan penunjang) beserta persyaratan kenaikan pangkat/jabatan setiap jenjang, apa dan bagaimana tahapan proses PKG beserta perangkat yang dibutuhkan, unsurunsur PKB dan kelengkapan bukti fisikyang dipersyaratkan, ketentuan dan tata cara penyusunan DUPAK. Berdasarkan rekap pilihan peserta 
pada pernyataan ini, penguasaan pengetahuan menunjukkan persentase perolehan $86,35 \%$. Kategori amat baik dalam penguasaan pengetahuan tersebut sebenarnya pun masih perlu pembuktian yang lebih nyata dimana peserta benarbenar bisa mengaplikasikan ilmu dan keterampilan yang dimiliki setelah mengikuti Diklat, dengan menindaklanjuti kewajiban yang harus dipenuhi terkait jabatan dan angka kredit yang dibutuhkan sesuai jenjang jabatan masingmasing. Hal ini yang justru menjadi perhatian dan harapan target akhir dilaksanakannya Diklat Teknis Substantif. Peserta-peserta yang menunjukkan hasil bagus perlu disertai dengan bukti nyata bahwa yang bersangkutan juga bagus di pasca mengikuti Diklat.

Unsur ketiga dari hasil belajar ini adalah keterampilan. Unsur keterampilan dilihat dari nilai produk, karena tentunya produk atau tugas yang dikumpulkan membutuhkan pemahaman konsep sekaligus keterampilan untuk bisa menyelesaikannya. Produk atau tugas tersebut dinilai oleh Widyaiswara dengan kriteriakriteria seperti: kebenaran cara mengisi dan isinya, kelengkapan yang diminta (kesesuaian antara nilai butir kegiatan yang diusulkan dengan bukti fisik yang disertakan), kebersihan dan kerapian, pemanfaatan file aplikasi secara langsung atau manual. Secara umum dapat dijelaskan bahwa lembar kerja mulai dari instumen EDG, instrumen PKG, laporan PD, dan format usulan DUPAK, peserta kerjakan dengan maksimal yaitu sesuai dengan kemampuan masing-masing. Ada yang mengisinya dengan lengkap, rinci, dan benar, ada juga sebagian yang mengerjakan atau mengisinya dengan lengkap tetapi ada beberapa yang perlu diperbaiki, ada pula yang mengisinya tidak terlalu lengkap tetapi sudah tepat. Widyaiswara memberi catatancatatan sebagai bahan perbaikan dan pengingat bagian-bagian yang perlu dipahami dan dilengkapi kembali oleh peserta. Nilai rata-rata peserta untuk keterampilan disini adalah 26,74 (bobot 30\%) atau jika dipersentase $89,13 \%$. Kemudian berdasar data dari kuesioner, diperoleh persentase $88,16 \%$. Hal ini bisa dimaknai pada kesiapan peserta untuk mengaplikasikan keterampilan yang dimiliki setelah mengikuti Diklat.

Ketiga unsur baik sikap, pengetahuan, dan keterampilan menghasilkan nilai rata-rata masing-masing adalah 91,4\%, $88,79 \%$, dan $88,64 \%$, rata-rata akhir adalah $89,61 \%$ atau pada kategori amat baik. Penjelasan komponen outcomes ini dapat disajikan dalam matrik judgement berikut 
Tabel 6 Judgement Matrix Komponen Outcomes

\begin{tabular}{|c|c|}
\hline \multicolumn{2}{|r|}{ Judgement Matrix } \\
\hline Standard & Judgement \\
\hline $\begin{array}{l}\text { Rekapitulasi nilai dari unsur } \\
\text { sikap (30\%), pengetahuan } \\
(40 \%) \text {, keterampilan (30\%), } \\
\text { diakumulasi minimal } \\
\text { mencapai nilai } 76 \text { untuk } \\
\text { dinyatakan lulus. }\end{array}$ & 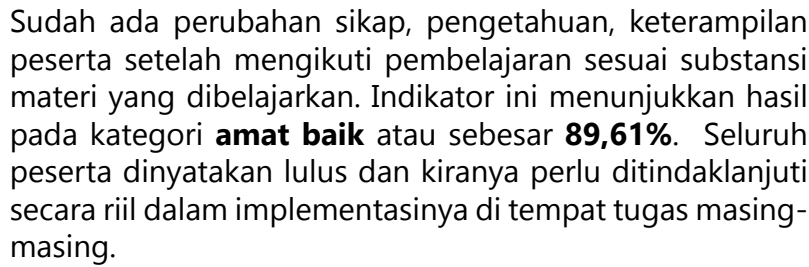 \\
\hline
\end{tabular}

Uraian dan hasil capaian dari masing-masing ketiga komponen di atas dapat dirangkum dalam tabel berikut.

Tabel 7 Rekapitulasi ketiga komponen fokus penelitian

\begin{tabular}{|c|l|c|c|}
\hline \multirow{2}{*}{ No } & \multirow{2}{*}{ Komponen } & \multicolumn{2}{|c|}{ Capaian } \\
\cline { 3 - 4 } & & Persentase & Kategori \\
\hline 1 & Antecedents & $89,80 \%$ & Amat Baik \\
\hline 2 & Transaction & $86,73 \%$ & Amat Baik \\
\hline 3 & Outcomes & $89,61 \%$ & Amat Baik \\
\hline & Rata-rata & $88,71 \%$ & Amat Baik \\
\hline
\end{tabular}

Tabel 7 tersebut menunjukkan bahwa secara umum hasil akhir evaluasi terhadap pembelajaran Diklat Teknis Substantif Peningkatan Kompetensi PKG dan PKB bagi Guru PAI SMA dan Guru Madrasah (MTs dan MA) di Lingkungan Kantor Kementerian Agama Kabupaten Sumbawa Tahun 2017 adalah pada kategori amat baik dengan persentase nilai sebesar $88,71 \%$. Kategori amat baik yang ditunjukkan pada ketiga fokus penelitian di atas, secara eksplisit menjelaskan keterkaitan antara antecedents, transaction, dan outcomes yang diharapkan dengan yang teramati. Jelas bisa diuraikan disini bahwa dengan perencanaan yang baik, proses pembelajaran akan berjalan dengan baik dan berujung pada hasil belajar yang baik pula. Persiapan mengajar Widyaiswara yang direncanakan dengan baik sesuai dengan standar minimal yang diatur dalam panduan penyelenggaraan Diklat teknis, berpengaruh pada kelancaran pelaksanaan proses pembelajaran Diklat. Skenario pembelajaran yang telah dipersiapkan, dengan segala kelengkapan bahan ajar dan lembar kerja, didukung dengan penguasaan kompetensi pengelolaan pembelajaran dan substansi yang mumpuni, memungkinkan pelaksanaan 
pembelajaran Diklat yang bermanfaat bagi peserta. Sesuai dengan teori dan yang diharapkan, pembelajaran melibatkan peserta semaksimal mungkin guna memberi pengalaman praktis dan bekal pengetahuan yang betubetul sesuai dengan kebutuhan dan tuntutan profesi guru. Sehingga hal ini berdampak pada pencapaian hasil belajar yang juga menunjukkan kategori amat baik.

\section{PENUTUP}

\section{Simpulan}

Berdasarkan paparan hasil penelitian dan pembahasan maka dapat disampaikan simpulan bahwa pembelajaran Diklat Teknis Substantif Peningkatan Kompetensi PKG dan PKB bagi Guru PAI SMA dan Guru Madrasah (MTs dan MA) di Lingkungan Kantor Kementerian Agama Kabupaten Sumbawa Tahun 2017 yang dievaluasi menggunakan model Countenance Stake menunjukkan hasil pada kategori amat baik dengan capaian nilai sebesar $88,71 \%$. Ketiga komponen yang menjadi fokus penelitian berada pada kategori amat baik, namun belum mencapai nilai maksimal $100 \%$ sehingga memerlukan tindak lanjut dalam upaya peningkatan kualitas proses pembelajaran maupun menindaklanjuti hasil yang diperoleh setelah mengikuti Diklat agar ada bukti nyata dan keberlanjutan implementasi pengetahuan dan keterampilan pasca Diklat sesuai dengan substansi materi yang diterima.

\section{Rekomendasi}

Sejalan dengan simpulan penelitian, peneliti menyampaikan beberapa rekomendasi sebagai berikut.

a. Kepada Balai Diklat Keagamaan Denpasar, untuk menindaklanjuti Diklat dalam bentuk kegiatan evaluasi pasca Diklat sehingga diperoleh informasi dan data yang jelas tentang keselarasan capaian peserta saat mengikuti Diklat dengan implementasinya di tempat tugas masing-masing.

b. Kepada Widyaiswara, agar selalu melengkapi dokumen persiapan mengajar sehingga tertib administrasi dan mempunyairancanganskenario yang jelas untuk diterapkan pada saat pelaksanaan proses pembelajaran sesuai tujuan pelaksanaan Diklat. Diharapkan Widyaiswara berusaha memperbarui ilmu dan pengetahuan yang dimiliki sesuai lingkup substansi yang disampaikan agar bisa memenuhi tuntutan kebutuhan peserta Diklat.

c. Kepada Stakeholder/ User di wilayah kerja, agar 
menindaklanjuti upaya diklat sesuai konteks diklat pemberdayaan kompetensi yang telah diikuti dan tugas dan keterampilan alumni pasca tanggung jawab profesi guru.

\section{DAFTAR PUSTAKA}

Arifin, Zainal. 2010. Model-model Evaluasi Program. Makalah (pdf). Jurusan Kurikulum dan Teknologi Pendidikan. Ilmu Pendidikan. Universitas Pendidikan Indonesia. Bandung.

Depdiknas. 2003. Undang-undang Republik Indonesia Nomor 20 Tahun 2003 tentang Sistem Pendidikan Nasional.

Kementerian PAN dan RB. 2009. Peraturan Menteri Pendayagunaan Aparatur Negara dan Reformasi Birokrasi Republik Indonesia Nomor 16 Tahun 2009 tentang Jabatan Fungsional Guru dan Angka Kreditnya

Kementerian PAN dan RB. 2014. Peraturan Menteri Pendayagunaan Aparatur Negara dan Reformasi Birokrasi Republik Indonesia Nomor 22 Tahun 2014 tentang Jabatan Fungisonal Widyaiswara dan Angka Kreditnya

Kemenag. 2015. Peraturan Menteri Agama Republik Indonesia Nomor 75 Tahun 2015 tentang Penyelenggaraan Pendidikan dan Pelatihan Pegawai pada Kementerian Agama

Lukum, Astin. 2015. Evaluasi Program Pembelajaran IPA SMP Menggunakan Model Countenance Stake. Jurnal Penelitian dan Evaluasi Pendidikan. Vol. 19 No. 1. dalam http://journal.uny.ac.id/index.php/jpep, diunduh pada 18 September 2017 pukul 09.33 wita

Miles, Matthew B. dan A. Michael Huberman. 1992. Qualitative Data Analysis. London: Sage Publication.

Pusdiklat Tenaga Teknis Keagamaan. 2007. Pedoman Evaluasi Pasca Diklat serta Pembinaan dan Pemberdayaan Alumni Diklat Tenaga Teknis Keagamaan di Lingkungan Departemen Agama. Jakarta: Pusdiklat Tenaga Teknis Keagamaan Badan Litbang dan Diklat Kementerian Agama RI.

Pusdiklat Tenaga Teknis Pendidikan dan Keagamaan. 2013. Pedoman Penyelenggaraan Diklat Teknis di Lingkungan Kementerian Agama. Jakarta: Pusdiklat Tenaga Teknis Pendidikan dan Keagamaan Badan Litbang dan Diklat Kementerian Agama RI. 
Pusdiklat Tenaga Teknis Pendidikan dan Keagamaan. 2013. Panduan Evaluasi Diklat Teknis di Lingkungan Kementerian Agama. Jakarta: Pusdiklat Tenaga Teknis Pendidikan dan Keagamaan Badan Litbang dan Diklat Kementerian Agama RI.

Sudaryanto, D.H. 2016. Pendekatan Prinsip Adult Learning dalam Upaya Menunjang Proses Pembelajaran Diklat Aparatur. Tersedia online pada http://pusdiklatmigas.esdm.go.id/portal_jurnal/readmore/165 